\title{
Factors Related to the Utilization of the Integrated Development Posts of Non-Communicable Diseases (POSBINDU PTM) in Bulili Health Centre Area
}

\author{
Vidyanto Untad (D)*, Muhammad Ryman Napirah (D), Novitayanti Pongsapan \\ Department of Health Administration and Policy, Faculty of Public Health, Tadulako University, Palu, Indonesia
}

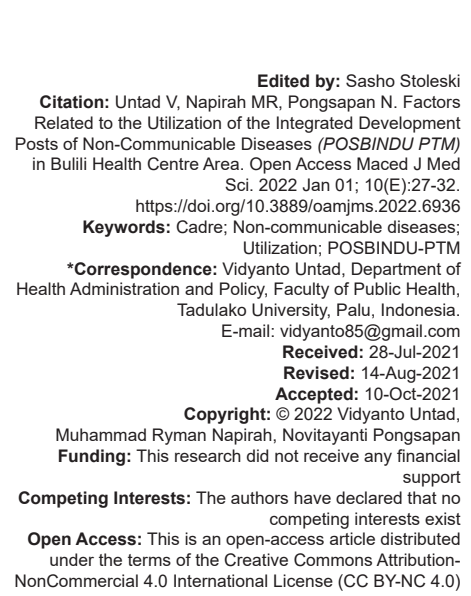

\section{Introduction}

In the world, non-communicable diseases (NCDs) have received serious attention with the inclusion of NCDs as one of the targets in the Sustainable Development Goals (SDGs) of 2030, especially Goal 3 , namely, ensure healthy lives and well-being. The inclusion of NCDs into the SDGs of 2030 implies that NCDs must become a national priority that requires cross-sector handling [1]. According to the WHO 2018 , around $71 \%$ of the causes of death worldwide are NCDs, killing 36 million people per year. About $80 \%$ of these deaths occur in middle- and low-income countries. NCDs currently cause $73 \%$ of deaths, $35 \%$ of them due to heart and blood vessel disease, $12 \%$ cancer, $6 \%$ by chronic respiratory diseases, $6 \%$ due to diabetes, and $15 \%$ due to other NCDs [2].

Indonesia is currently faced with health development in the Triple Burden, namely infectious diseases, NCDs, and re-emerging diseases. The pattern of disease is currently undergoing an epidemiological transition. The increasing prevalence of several major NCDs is increasing, while communicable diseases are still high, further exacerbated by the emergence of new diseases and the re-emergence of old diseases. This is due to an unhealthy lifestyle, which is driven by urbanization, modernization, and globalization.

The results of Riskesdas (2018) show a high prevalence of NCDs in Central Sulawesi Province, such as hypertension (34.1\%), heart disease (1.5\%), stroke $(10.9 \%)$, diabetes mellitus $(1.5 \%)$, asthma $(2.4 \%)$, chronic kidney $(3.8 \%)$, joint disease $(7.3 \%)$, and cancer/tumor (1.8\%) [3]. Based on the Palu City Health Office of Palu, Central Sulawesi, in 2019, the comprehensive report of NCD cases for new cases and old cases reached 41,217 people; the highest was cases of hypertension about 19,772 people followed by diabetes mellitus of 9718 people, while osteoporosis of 3251 and coronary heart disease of 3178 people for old cases and new cases [4].

Various efforts have been made to prevent and control NCDs, in line with the WHO approach 
to the main NCDs associated with common risk factors. Establishing an Integrated Development Post (in Indonesian is: Pos Pembinaan Terpadu, abbreviated as POSBINDU) for NCDs (in Indonesian is: Penyakit Tidak Menular, abbreviated as PTM) has been initiated at the community level, where early detection of risk factors, counseling, and community activities toward a Clean and Healthy Life Behavior (In Indonesian is: Perilaku Hidup Bersih dan Sehat, abbreviated as $P H B S$ ) has been initiated. There has also been strengthening of the PUSKESMAS as the community's first contact to the health system [5]. The utilization of the POSBINDU in almost all regions in Indonesia is still facing various problems. These problems, including the low target coverage $(<40 \%)$, the low role of cadres, no health education, no total cholesterol and triglycerides, lack of coordination between cadres and health center (In Indonesian is: Pusat Kesehatan Masyarakat, abbreviated as PUSKESMAS) health officers, lack of commitment from PUSKESMAS as a coaching team, lack of cross-sector collaboration with POSBINDU programs, people are not motivated to become cadres [6].

This study aimed to analyze the relationship between knowledge, access, facilities and infrastructure, health cadre support, health center officer support, family support toward the Utilization of Integrated Development Post of NCD (POSBINDU-PTM) under the working area of Bulili Health Center, Palu City.

\section{Methods}

It was quantitative research with an analytical survey design using a cross-sectional design. The population of this study was the entire community in the working area of the Bulili Health Center, aged $15-59$ years, totaling 15,183 people. About 100 people were involved as a sample, calculated using the Solvin formula and Stratified Random Sampling in two villages located in the working area of the Bulili Health Center, 50 respondents in the South Birobuli Village and 50 respondents in the Petobo Village.

The data collected are the characteristics of respondents, and knowledge, access to POSBINDUPTM, facilities and infrastructure, health cadres support, health officer support, and family support toward the utilization of POSBINDU-PTM. The data collection process uses a questionnaire that has been tested for validity and reliability.

The data were analyzed through data processing using Microsoft Excel and Statistical Packages for Social Science using the Chi-square test and the significance level is $p<0.05$

\section{Results and Discussion}

\section{Characteristics of respondents}

The characteristics of respondents involved in this study based on age, gender, education, and occupation can be seen in Table 1. This study involved 16-56 years old respondents, dominated by the age group 16-20 years, about 27 people (27\%). Female respondents also dominated (64\%) compared to males $(36 \%)$. In general, the respondents involved have a high school education background $(60 \%)$, while some of them were universities (16\%), junior high schools (12\%), and elementary schools (12\%). Then, based on occupation, the housewife was the majority $(41 \%)$ among others.

Table 1: Distribution of respondents based on characteristics

\begin{tabular}{lll}
\hline Characteristics & $\mathrm{n}$ & $\%$ \\
\hline Age (y.0) & 27 & \\
$16-20$ & 12 & 27.0 \\
$21-25$ & 10 & 12.0 \\
$26-30$ & 14 & 10.0 \\
$31-35$ & 12 & 14.0 \\
$36-40$ & 9 & 12.0 \\
$41-45$ & 11 & 9.0 \\
$46-50$ & 5 & 11.0 \\
$51-56$ & 100 & 5.0 \\
Total & & 100 \\
Gender & 36 & \\
Males & 64 & 36.0 \\
Females & 100 & 64.0 \\
Total & & 100 \\
Education & 12 & 12.0 \\
Elementary school & 12 & 12.0 \\
Junior high school & 60 & 60.0 \\
Senior high school & 16 & 16.0 \\
University & 100 & 100 \\
Total & & \\
Occupation & 2 & 2.0 \\
Farmer & 41 & 41.0 \\
Housewife & 3 & 3.0 \\
Civil servants & 1 & 1.0 \\
Pensionary & 19 & 19.0 \\
Students & 1 & 1.0 \\
Laborer & 14 & 14.0 \\
Self-employed & 4 & 4.0 \\
Trader & 12 & 12.0 \\
College student & 3 & 3.0 \\
Others & 100 & 100 \\
Total & & \\
\hline & & \\
\hline
\end{tabular}

The distribution of respondents based on the dependent and independent variables in this study was presented in Table 2. These variables were the utilization of POSBINDU-PTM, Knowledge, access, facilities and infrastructure, support of health cadres, and support of health center officers.

\section{Correlation between variables and utility of POSBINDU-PTM}

Table 3 shows that knowledge, access to POSBINDU-PTM, facilities and infrastructure, health cadres support, health officer support, and family support have a significant correlation to the utilization of POSBINDU-PTM with a significance level of $p<0.05$.

\section{Knowledge}

Knowledge is a fundamental domain in forming an action. Before a person adopts a behavior, he must 
know the meaning or benefits of the behavior, including using health services [7].

Table 2: Distribution of respondents based on the dependent and independent variables

\begin{tabular}{lll}
\hline Variables & $\mathrm{n}$ & $\%$ \\
\hline The utility of POSBINDU-PTM & 78 & 78.0 \\
No & 22 & 22.0 \\
Yes & 100 & 100 \\
$\quad$ Total & & \\
Knowledge & 60 & 60.0 \\
$\quad$ Poor & 40 & 40.0 \\
Good & 100 & 100 \\
$\quad$ Total & & \\
Accessibility & 70 & 70.0 \\
Far & 30 & 30.0 \\
Close & 100 & 100 \\
Total & & \\
Facilities and infrastructure & 70 & 70.0 \\
$\quad$ Not available & 30 & 30.0 \\
Available & 100 & 100 \\
Total & & \\
Health cadres support & 79 & 79.0 \\
$\quad$ None & 21 & 21.0 \\
Yes & 100 & 100 \\
$\quad$ Total & & \\
Health officer support & 77 & 77.0 \\
$\quad$ None & 23 & 23.0 \\
Yes & 100 & 100 \\
$\quad$ Total & & \\
\hline
\end{tabular}

Based on the results of statistical tests using the Chi-square test conducted between knowledge and utilization of POSBINDU-PTM, the results obtained a $p=0.005$ with $\alpha=0.05$, which means that there was a relationship between Knowledge and utilization of POSBINDU-PTM in the Bulili Health Center area of Palu City. Knowledge of POSBINDU-PTM is one factor that determines someone to come to this health service. The lack of public understanding about the benefits of this health services activity and the irregular schedule every month resulted in low utilization. Then, information related to POSBINDU-PTM has not been comprehensive and has not been evenly distributed to the community, then lower utilization rates. The results of this study are also in line with [8], which showed a significant effect between knowledge and the use of POSBINDU in the working area of the Wawonasa Health Center, Manado, with a $p=0.001<0.05$.

Table 3: Correlation of independent variables and the utility of POSBINDU-PTM

\begin{tabular}{|c|c|c|c|c|c|c|c|}
\hline \multirow[t]{3}{*}{ Variables } & \multicolumn{4}{|c|}{ POSBINDU-PTM utility } & \multirow{2}{*}{\multicolumn{2}{|c|}{ Total }} & \multirow{3}{*}{$\begin{array}{l}p \text {-value } \\
(\alpha=0.005)\end{array}$} \\
\hline & \multicolumn{2}{|c|}{ No } & \multicolumn{2}{|c|}{ Yes } & & & \\
\hline & $\mathrm{n}$ & $\%$ & $\mathrm{n}$ & $\%$ & $\mathrm{n}$ & $\%$ & \\
\hline \multicolumn{8}{|l|}{ Knowledge } \\
\hline Poor & 53 & 88.3 & 7 & 11.7 & 60 & 100 & \multirow[t]{2}{*}{0.005} \\
\hline Good & 25 & 62.5 & 15 & 37.5 & 40 & 100 & \\
\hline \multicolumn{8}{|l|}{ Accessibility } \\
\hline Far & 69 & 98.6 & 1 & 1.4 & 70 & 100 & \multirow{2}{*}{0.000} \\
\hline Near & 9 & 30.0 & 21 & 70.0 & 30 & 100 & \\
\hline \multicolumn{8}{|c|}{ Facilities and infrastructure } \\
\hline Not available & 70 & 100 & 0 & 0 & 70 & 100 & \multirow[t]{2}{*}{0.000} \\
\hline Available & 8 & 26.7 & 22 & 73.3 & 30 & 100 & \\
\hline \multicolumn{8}{|c|}{ Health cadres support } \\
\hline None & 78 & 98.7 & 1 & 1.3 & 79 & 100 & \multirow[t]{2}{*}{0.000} \\
\hline Yes & 0 & 0 & 21 & 100 & 21 & 100 & \\
\hline \multicolumn{8}{|c|}{ Health officers support } \\
\hline None & 77 & 100 & 0 & 0 & 77 & 100 & \multirow[t]{2}{*}{0.000} \\
\hline Yes & 1 & 4.3 & 22 & 97.5 & 23 & 100 & \\
\hline \multicolumn{8}{|l|}{ Family support } \\
\hline None & 76 & 98.3 & 1 & 1.3 & 77 & 100 & \multirow[t]{2}{*}{0.000} \\
\hline Yes & 2 & 8.7 & 21 & 91.3 & 23 & 100 & \\
\hline
\end{tabular}

In this study, it was found that most respondents did not know about the existence of POSBINDU-PTM around their homes, and even many respondents had just heard of it. This shows that the information obtained by the community was still lack and only a small number of respondents were aware of this POSBINDU-PTM. However, this study is inversely proportional to Kilic et al. (2016) [9] research, no relationship between knowledge and controlling high blood pressure or hypertension in the work area of the health center in Yozgat Province, Turkey. Furthermore, most people have medium and high knowledge. This shows that patients or people in Turkey have better knowledge and awareness about high blood pressure or hypertension.

\section{Accessibility}

Distance is a measure of how close one place is to another. Distance from a place of residence can be a driving factor because the distance between them can affect a person in carrying out activities. The further the distance traveled, the lower a person's motivation to visit health services [10].

The Chi-square test was conducted between access to POSBINDU-PTM and its utilization obtained $p=0.000(\alpha=0.05)$. It means a significant relationship between access to the POSBINDU-PTM and the utilization in the Bulili Health Center area of Palu City. Access and distance of residence are the factors that influence people to come to the health center. Some respondents have a long distance from their homes to this place, so they will not use this facility. Then, there are no vehicles used to POSBINDU-PTM because some people say their families use vehicles to go to work which makes them not use this health facility. The same finding is also revealed by Aina (2019) [11]; there is a relationship between house distance and community participation in POSBINDU-PTM activities in Tugurejo Slahung Ponorogo Village with a $\mathrm{p}(0.008)<(0.05)$.

This study showed that some respondents stated that their homes were too far from the POSBINDU-PTM location. They stated that they did not have a motorbike to ride, and no family could take them to this place. It became an obstacle for them not participating in the POSBINDU-PTM. This is inversely proportional to research by Liansyah (2014) [12], which states that no significant relationship between access to POSBINDU for the elderly and its use in the Beji Health Center area of Depok City, with a $p=0.42(>0.05)$. This study shows that although the location of POSBINDU according to the elderly is far and challenging, the support from the family is quite good, such as taking the elderly to the Posbindu service place, the elderly can access these services quickly.

\section{Facilities and infrastructures}

The availability of facilities and infrastructure is one of the enabling factors in health behavior [13]. The $p=0.000<0.05$ was found between facilities and infrastructure with the utility of POSBINDU-PTM. There was a significant relationship between facilities 
and infrastructure to its utilization in the Bulili Health Center area of Palu City. The availability of facilities and infrastructure in the form of POSBINDU-PTM in the working area of the Bulili Health Center was still inadequate. The location of it was not fixed, so people did not know the location of the POSBINDU-PTM. A report shows that in order to achieve the target of public examination, health workers carry out examinations every month by changing locations. A study showed that based on the guidelines for the implementation of the PTM Posbindu, the place for the implementation of the PTM Posbindu should be in a location that is easily accessible and convenient for participants and can be carried out in various places [14]. The place for the implementation of the PTM Posbindu has not met the Standard Operating Procedure, because there are several buildings where the PTM Posbindu is carried out making the community uncomfortable to participate in the PTM Posbindu activities when its implementation is combined with other community activities [15].

Then, the lack of public knowledge makes them unaware of the facilities and infrastructure in the POSBINDU-PTM and the lack of information and counseling from health workers about the POSBINDU$P T M$ so that some people do not use it. This result is in line with the research of Sari and Savitri [6] obtained a $p=0.013$ which means there is a relationship between the availability of this facility and the utilization of the working area of the Setiabudi District Health Center, South Jakarta City. In this study, the availability of complete facilities in several POSBINDU-PTM was due to a partnership. However, the results of this study are inversely proportional to the research of Liansyah (2014) [12], which shows that there is no significant relationship between health facilities and the use of POSBINDU in the work area of Beji Health Center, Depok City, in 2014, with a value of $=0.42>0.05$. Most of the elderly actively visit these health services compared to those who do not visit due to the perception of the elderly themselves who experience various disease complaints, so they need to check their health.

\section{Health cadres support}

Health cadres are adults, both men, and women who are seen as people who have advantages in society in successful activities, establishing good relationships with others, socioeconomic status, and others [16]. The implementation of the POSBINDU$P T M$ is carried out by existing health cadres or several people from each group, organization or institution, or workplace who are willing to hold the POSBINDU-PTM with the criteria of having a minimum of high school education, willing and able to carry out activities related to the POSBINDU-PTM [17]. Based on the results of statistical tests using the Chi-square test conducted between the support of health cadres and the use of Posbindu PTM, the results obtained a $p=0.000$. It means a significant relationship between Health Cadre Support and the utilization of POSBINDU-PTM in the Bulili Health Center area of Palu City.

The role of cadres is one of the factors that make people visit POSBINDU. Most of the community stated that they had never received any socialization or information about this health service from health workers or cadres. The lack of good respondent behavior in utilizing health services is strongly influenced by cadres' continuously approaching and providing health information to the community. The lack of cadre initiative in inviting the community to check their health at this health service also causes a lack of community motivation to visit. This causes the need to monitor and evaluate the implementation of POSBINDU-PTM so that the quality of service becomes better. The results of this study are also in line with the research of Tanjung et al. [18], which stated that health cadres affected the utilization of the integrated NCD development post in the Batang Toru Health Center work area, South Tapanuli Regency in 2017, with a $p=0.000<0.05$.

In this study, it was found that the role of cadres affected the utilization of the POSBINDU-PTM. The existence of cadre support encourages its utilization behavior to feel comfortable and willing to come to this health services. However, research by Astriani et al. [19] stated that there is no significant relationship between cadre support and the use of POSBINDUPTM of Mulawarman University with a $p=0.171$ ( $p>$ $0.05)$. Although statistically, the study results show no significant relationship between the role of cadres and the utilization at Mulawarman University. This study reveals several reasons for the absence of respondents in POSBINDU-PTM activities; respondents do not know the schedule, and sometimes it is held suddenly, but they are not informed about the benefits. In addition, the crowded queues at the time of the examination in the POSBINDU-PTM of Mulawarman University became a complaint of several respondents.

\section{Health officer supports}

Health worker support is social support in informative support and provides fairly clear information about things known to the Kemenkes [20]. The statistical tests using the Chi-square test conducted between the support of health workers and PTM Posbindu used the results obtained $p=0.000<0.05$. There was a significant relationship between Health Officer Support and the utilization of POSBINDU-PTM in the Bulili Health Center area of Palu City.

Health workers are responsible for the improvement of public health knowledge. Health workers actively provide information about POSBINDU-PTM and encourage the community to take advantage of it. Health workers must determine a fixed schedule every month and carry it out routinely so that the program will run well and prevent risk factors as early as possible to 
reduce the number of NCDs. These results align with research by Peck et al. [21], which states a relationship between the availability of facilities and infrastructure and utilization in health facilities in Saharan Africa.

This study shows that human resources for the treatment of NCDs are still very lacking. Furthermore, the lack of knowledge and experience of health workers is the main barrier in caring for people who have NCDs in sub-Saharan Africa. However, the results of this study are inversely proportional to the research of Sari and Savitri [6] obtained a $p=0.28$ which means there is no relationship between health workers and the utilization in the work area of the Setiabudi Sub-district Health Center, South Jakarta City. In this study, health workers are always present during the implementation of the $P O S B I N D U-P T M$ and always carried out identification activities for NCDs.

\section{Family supports}

Family support is one factor that influences the formation and development of individual behavior by increasing the emotional, informative support provided by family members both in the physical environment and in the socio-psychological environment [22].

Based on the results of statistical tests using the Chi-square test conducted between family support and the utilization of POSBINDU-PTM, obtained $p=0.000<0.05$. There was a significant relationship between family support and its utility in the Bulili Health Center area of Palu City. These results are in line with the research by Bayu [8], which showed that there is a significant effect between family support and the use of POSBINDU in the work area of the Wawonasa Health Center, Manado, with a $p=0.001<0.05$. Most respondents lack family support because their families do not know and do not receive information about this health service. However, Astriani et al. [19] research find no significant relationship between family support and the use of POSBINDU-PTM in Mulawarman University, with a $p=0.92>0.05$. Although statistically, the results of this study indicate no significant relationship, in theory, family support affects the utilization of health services.

According to our results, family support for health care providers makes people able to develop a tendency to do positive things, such as supporting selfconfidence and making a person behave healthily.

\section{Conclusion}

There is a correlation between knowledge, access, facilities, health cadres, health officers, and family support toward utilizing the Integrated
Development Post of NCD in the working area of the Bulili Health Center, Palu City. This study indicates that the utilization of POSBINDU-PTM is still very low only $22 \%$. Efforts are needed from various parties through regular promotion and counseling and providing information about the benefits. It is suggested that the health center/PUSKESMAS will pay more attention to the POSBINDU-PTM program, especially the Utilization of POSBINDU-PTM. The socialization of the schedule also needs to be improved and determined the expected place for health workers to increase information and counseling to the public. Health workers should invite the community to become health cadres to assist in carrying out the activities. The community can participate as health cadres. They can assist health workers in running the POSBINDU-PTM program. In addition, it is necessary to evaluate and monitor every month to assess the success of the utilization of this health service.

\section{References}

1. Kemenkes RI. Rencana Aksi Strategi Nasional Pencegahan dan Pengendalian Penyakit Tidak Menular 2015-2019. Jakarta: Kementerian Kesehatan RI; 2017

2. Kemenkes RI. Buku Pedoman Manajemen Penyakit Tidak Menular. Jakarta: Kementerian Kesehatan Republik Indonesia; 2019.

3. Dinas Kesehatan Provinsi Sulawesi Tengah. Profil Kesehatan Provinsi Sulawesi Tengah Tahun 2018. Palu: Dinas Kesehatan Provinsi Sulawesi Tengah; 2018.

4. Dinas Kesehatan Kota Palu Sulawesi Tengah. Laporan Kasus Penyakit Tidak Menular. Palu: Dinas Kesehatan Kota Palu Sulawesi Tengah; 2019.

5. Permenkes RI. Peraturan Menteri Kesehatan Republik Indonesia Nomor 5 Tahun 2017 Tentang Rencana Aksi Nasional Penanggulangan Penyakit Tidak Menular Tahun 2015-2019. Kementerian Kesehatan RI; 2017.

6. Sari DWR, Savitri M. Factors related to the Utilization of POSBINDU for Non-Communicable Diseases (PTM) in the Work Area of PUSKESMAS, Setia Budi District, South Jakarta City in 2018. J Kebijakan Kesehatan Indonesia. 2018;7(2):49-56.

7. Notoatmodjo S. Metodologi Penelitian Kesehatan. Jakarta: Rineka Cipta; 2012.

8. Bayu D. Analisis Faktor Yang Mempengaruhi Pemanfaatan Pos Pembinaan Terpadu Penyakit Tidak Menular. Jakarta: Universitas Muhammadiyah Jakarta; 2019.

9. Kilic M, Uzunçakmak T, Ede H. The effect of knowledge about hypertension on the control of high blood pressure. Int $\mathrm{J}$ Cardiovasc Acad. 2016;2(1):27-32.

10. Nasruddin NR. Faktor-Faktor Yang Mempengaruhi Pemanfaatan Posbindu PTM Di Wilayah Kerja Puskesmas Ballapang Kota Makassar Tahun 2017. Makassar: Universitas Islam Negeri Alauddin; 2017.

11. Aina TA. Faktor Predisposing, Enabling, Dan Reinforcing Yang Berhubungan Dengan Keikutsertaan Masyarakat Dalam Posbindu PTM Di Desa Tugurejo Slahung Ponorogo. Madiun: Stikes Bhakti Husada Mulia Madiun; 2019.

12. Liansyah W. Faktor Faktor yang Berhubungan dengan Pemanfaatan Pelayanan Posbindu Lansia di Wilayah Kerja 
Puskesmas Beji. Depok: Universitas Indonesia; 2014.

13. Green L, Kreuter M. Health Program Planning: An Educational and Ecological Approach. $4^{\text {th }}$ ed. New York: McGraw-Hill Humanities/Social Sciences/Languages; 2004. p. 600.

14. Kemenkes RI. Buku Pintar Kader Penyelenggaraan Posbindu Ptm. Jakarta: Kementerian Kesehatan RI; 2013.

15. Putri RE, Hubaybah, Asparian. Evaluation of the implementation process of posbindu PTM in working area of simpang sungai duren public health center of Jambi subdistrict of muaro Jambi Regency in 2017. J Kesmas Jambi. 2018;2(1):12-27.

16. Kemenkes RI. Pedoman Pembinaan Kesehatan Lanjut Usia Bagi Petugas Kesehatan. Jakarta: Direktorat Bina Kesehatan Komunitas; 2010.

17. Depkes RI. Pedoman Surveilans Penyakit Jantung dan Pembuluh Darah. Jakarta: Departemen Kesehatan RI; 2007.

18. Tanjung WW, Harahap YW, Panggabean MS. Factors Affecting the Utilization of the Integrated Guidance Post Program NonCommunicable Diseases in the Work Area of the Batang Toru
Health Center, South Tapanuli Regency in 2017. J Kesehatan IImiah Indonesia (Indonesian Health Scientific Journal). 2018;3(2):92-108.

19. Astriani D, Duma K, Sihotang FA. Factors Affecting the Integrated Non-Communicable Disease Development Post (POSBINDU PTM). Verdure Health Sci J. 2020;2(1):40-50.

20. Kemenkes RI. Dukungan Petugas Kesehatan. Jakarta: Kementerian Kesehatan RI; 2014.

21. PeckR, Mghamba J, Vanobberghen F, Kavishe B, Rugarabamu V Smeeth $L$, et al. Preparedness of Tanzanian health facilities for outpatient primary care of hypertension and diabetes: A crosssectional survey. Lancet Glob Health. 2014;2(5):e285-92. https://doi.org/10.1016/S2214-109X(14)70033-6 PMid:24818084

22. Pedrosa $A L$, Bitencourt L, Fróes AC, Cazumbá ML, Campos RG, de Brito SB, et al. Emotional, behavioral, and psychological impact of the COVID-19 pandemic. Front Psychol. 2020;11:566212. https://doi.org/10.3389/fpsyg.2020.566212 PMid:33117234 